\title{
Isolation of Staphylococcus epidermidis from inflamed upper respiratory tract of an orange-spined hairy dwarf porcupine (Sphiggurus villosus)
}

\author{
Fornazari F (1, 2), Guimarães FF (1), Teixeira CR (2), Langoni H (1)
}

(1) Zoonosis Research Center (NUPEZO), Department of Veterinary Hygiene and Public Health (DHVSP), School of Veterinary Medicine and Animal Husbandry (FMVZ), São Paulo State University (UNESP - Univ Estadual Paulista), Botucatu, São Paulo State, Brazil; (2) Wildlife Research and Medical Center (CEMPAS), Department of Veterinary Surgery and Anesthesiology (DCAV), School of Veterinary Medicine and Animal Husbandry (FMVZ), São Paulo State University (UNESP - Univ Estadual Paulista), Botucatu, São Paulo State, Brazil.

\begin{abstract}
The orange-spined hairy dwarf porcupine (Sphiggurus villosus) is a rodent species common in most parts of South America, and little is known about the pathologies that can afflict it. A specimen was delivered at the Wildlife Research and Medical Center (CEMPAS), School of Veterinary Medicine and Animal Husbandry, UNESP, Botucatu, SP, Brazil. The animal showed intense apathy, with purulent secretion in the nasal cavity and fracture of the lumbar spine. Due to the unfavorable prognosis, the porcupine was euthanized and microbiological culture of nasal discharge showed Staphylococcus epidermidis. The antimicrobial resistance test revealed sensitivity to all tested antimicrobials (ampicillin, oxacillin, tetracycline, penicillin G, neomycin, cephalexin, gentamicin, enrofloxacin, ciprofloxacin, cotrimoxazol, cefoxitin and cephalothin). This bacterium is part of the nasal flora of humans and other animals, and may cause infection under certain conditions. In the present study, the infection and colonization by $S$. epidermidis was the probable cause of the inflammatory process. The sensitivity to all tested antimicrobials suggests that this strain has not been previously exposed to such drugs.
\end{abstract}

Key words: Staphylococcus epidermidis, orange-spined hairy dwarf porcupine, Sphiggurus villosus, antimicrobials, susceptibility.

\section{INTRODUCTION}

Orange-spined hairy dwarf porcupines (Sphiggurus villosus) belong to Erethizontidae family and are distributed throughout South America (1). According to the International Union for Conservation of Nature (IUCN), its status is considered as "less concern". Numerous Brazilian zoos keep such animals in their collection, developing activities addressed to entertainment, education and research. Studies involving pathologies that may affect this porcupine species are very scarce.

Inflammatory processes located at the nasal cavity are frequent in humans and other animals. It is still unknown whose mechanisms are related to the cause of this disease, and the involvement of infectious agents, such as bacteria and fungi, has been investigated (2). The present study aimed to report the isolation of Staphylococcus epidermidis from a free-ranging orange-spined hairy dwarf porcupine associated with upper respiratory tract inflammation.

\section{CASE REPORT}

An adult orange-spined hairy dwarf porcupine was delivered at the Wildlife Research and Medical Center (CEMPAS), School of Veterinary Medicine and Animal Husbandry, UNESP, Botucatu, Brazil. At physical examination the animal presented intense apathy, paralysis of the hind limbs and bilateral purulent discharge from the nasal cavity (Figure 1). 


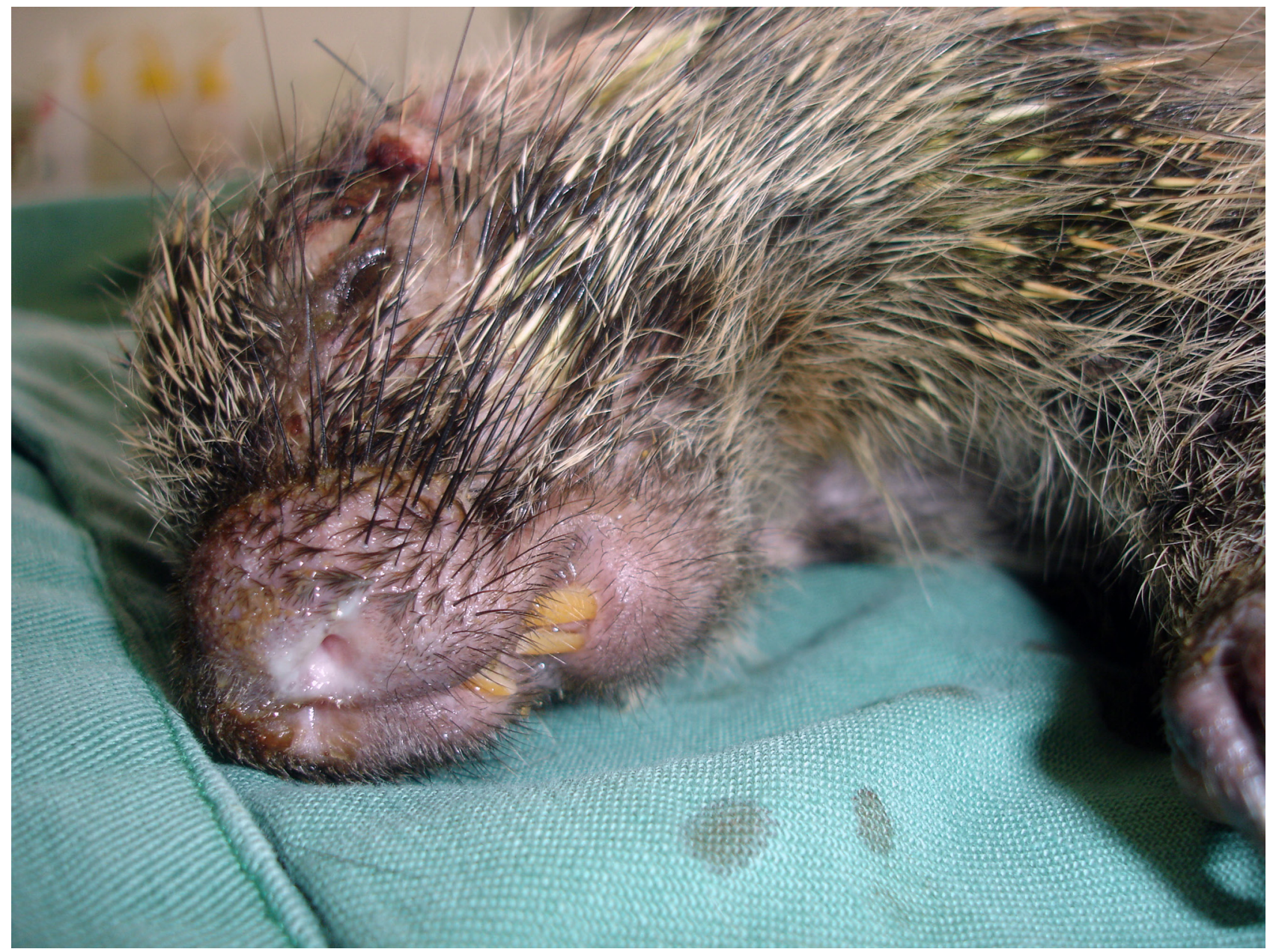

Figure 1. An orange-spined hairy dwarf porcupine (Sphiggurus villosus) had purulent discharge from the nasal cavity. Botucatu, SP, 2011.

A complete radiographic exam was performed, and revealed a traumatic fracture of the lumbar spine. The purulent secretion from the nasal cavity was collected for microbiological culture with a sterile swab. The culture was performed using ovine blood agar (5\%) and MacConckey agar medias, incubated in aerobiosis $\left(37^{\circ} \mathrm{C}\right)$ for 72 hours. The bacteria were identified according to Kloos and Schleifer (3) modified by Cunha et al. (4) method, and were found to be Staphylococcus epidermidis.

The antimicrobial resistance was tested in vitro by the disc diffusion method using the main antimicrobials employed in human therapy against staphylococcal infection (5). The antimicrobial sensitivity discs (Oxoid $^{\oplus}$, Basingstoke, England) were ampicillin $(10 \mu \mathrm{g})$, oxacillin $(1 \mu \mathrm{g})$, tetracycline $(30 \mu \mathrm{g})$, penicillin $\mathrm{G}(10 \mu \mathrm{g})$, neomycin $(10 \mu \mathrm{g})$, cephalexin $(30$ $\mu \mathrm{g})$, gentamicin $(120 \mu \mathrm{g})$, enrofloxacin $(5 \mu \mathrm{g})$, ciprofloxacin $(5 \mu \mathrm{g})$, cotrimoxazol $(25 \mu \mathrm{g})$, cefoxitin $(30 \mu \mathrm{g})$ and cephalothin $(30 \mu \mathrm{g})$. Isolates were categorized as susceptible, intermediary or resistant based on criteria developed by the National Committee for Clinical Laboratory Standards. S. epidermidis ATCC 12228 strains were used as control (6). The isolate was sensitive to all tested antimicrobials.

Due to the unfavorable prognosis, the animal was euthanized and submitted to a necroscopic examination. No macroscopic abnormalities were observed, besides the findings of the physical and radiographic examinations. A histopathological analysis could not be performed. No macroscopic abnormality was observed in the lower respiratory tract, and the purulent discharge was restricted to the nasal cavity, which suggested an inflammatory process located at this organ.

\section{DISCUSSION}

Bacteria of genus Staphylococcus belong to the commensal flora of humans and other animals and may act as opportunist pathogenic 
agents under determined conditions $(7,8) . S$. epidermidis is considered one the most common species of this genus, and is frequently isolated from several inflamed tissues and organs, including the nasal cavity (9-11). In the present study, the abnormalities observed in the physical and necroscopic examinations indicated an inflammatory process restricted to the nasal cavity. Therefore, the isolation of S. epidermidis indicates that it was the predominant bacterium in the organ.

In dogs and cats, primary bacterial rhinitis is rare and is usually secondary to other conditions, such as trauma, neoplasia, reflux, foreign body ingestion etc. (12).

Information regarding rhinitis in wildlife is scarce. A few studies involving different species, particularly tortoises, indicated virus and bacteria as the etiological agents (13-18). In such cases, other organs and tissues may also be injured, and a systemic manifestation may also occur. Campbell et al. (14) described septicemia caused by Staphylococcus aureus in a captive group of ground squirrels (Citellus lateralis) in Northern California, USA. The predominant findings consisted of suppurative lesions in several organs, including purulent rhinitis and sinusitis with abscess formation. Since a detailed history of the porcupine was not available and the animal had to be euthanized, further investigation related to the etiology of this pathology could not be performed.

The high sensitivity to all tested antimicrobials suggests that this strain had no previous contact with such drugs, which would result in a selection of resistant microorganisms. This situation is frequent in cases of domestic animals and human infections by Staphylococcus spp. (19). The hypothesis is reinforced by the animal origin, since a wild species has less probability of having contact with antimicrobials.

In the present case the nasal cavityinflammation was associated with Staphylococcus epidermidis infection, but it is uncertain if this bacterium was the cause of the lesion. S. epidermidis is part of the nasal microbial flora of domestic animals and humans. Therefore, it is probable also found in the nasal cavity of orange-spined hairy dwarf porcupines. Due to the high sensitivity to several antimicrobials, the present strain is not common in animal or human infections.

\section{COPYRIGHT}

(C) CEVAP 2012

\section{SUBMISSION STATUS}

Received: May 14, 2012.

Accepted: August 14, 2012.

Abstract published online: September 3, 2012.

Full paper published online: November 30, 2012.

\section{CONFLICTS OF INTEREST}

The authors declare no conflicts of interest.

\section{CORRESPONDENCE TO}

Felipe Fornazari, Núcleo de Pesquisas em Zoonoses (NUPEZO), Departamento de Higiene Veterinária e Saúde Pública, Faculdade de Medicina Veterinária e Zootecnia, UNESP, Distrito de Rubião Jr, s/n, Botucatu, SP, 18618970, Brasil. Phone: +551438116270 ext. 23. Fax: +551438116075. Email: ff_vet@yahoo.com.br.

\section{REFERENCES}

1. Lange RR, Schmidt EMS. Rodentia - Roedores Silvestres. In: Cubas ZS, Silva JCR, Catão-Dias JL, editors. Tratado de Animais Selvagens. São Paulo: Roca; 2006. p. 475-91.

2. Mantovani K, Bisanha AA, Demarco RC, Tamashiro E, Martinez R, Anselmo-Lima WT. Maxillary sinuses microbiology from patients with chronic rhinosinusitis. Braz J Otorhinolaryngol. 2010;76(5):548-51.

3. Kloos WE, Schleifer KH. Isolation and characterization of staphylococci from human skin. Descriptions of four new species: Staphylococcus warneri, Staphylococcus capitis, Staphylococcus hominis, Staphylococcus simulans. Int J Syst Bacteriol.1975;25(1):62-79.

4. Cunha M de L, Sinzato YK, Silveira LV. Comparison of methods for the identification of coagulasenegative staphylococci. Mem Inst Oswaldo Cruz. 2004;99(8):855-60.

5. Bauer AW, Kirby WM, Sherris JC, Turck M. Antibiotic susceptibility testing by a standardized single disk method. Am J Clin Pathol. 1966;45(4):493-6.

6. Clinical and Laboratory Standards Institute. Performance standards for antimicrobial disk susceptibility tests. $10^{\text {th }}$ ed. Approved standard M2A10. Wayne, PA: Clinical and Laboratory Standards Institute; 2009.

7. Bagcigil FA, Moodley A, Baptiste KE, Jensen VF, Guardabassi L. Occurrence, species distribution, antimicrobial resistance and clonality of methicillinand erythromycin-resistance staphylococci in the nasal cavity of domestic animals. Vet Microbiol. 2007;121(3-4):307-15.

8. Iwase T, Uehara Y, Shinji H, Tajima A, Seo H, Takada $\mathrm{K}$, et al. Staphylococcus epidermidis Esp inhibits Staphylococcus aureus biofilm formation and nasal colonization. Nature. 2010;465(7296):346-9. 
9. Ohara-Nemoto Y, Haraga Y, Kimura S, Nemoto TK. Occurence of staphylococci in the oral cavities of healthy adults and nasal oral trafficking of the bacteria. J Med Microbiol. 2008;57(Pt 1):95-9.

10. Olszewski J, Milonski J. The analysis of the bacterial and fungal flora in maxillary sinuses in patients operated due to FESS method. Otolaryngol Pol. 2008;62(4):458-61.

11. Romanenko EE, Baturo AP, Mokronosova MA, Tarasova GD, Sergeev AV. Microflora of the nasal mucosa in allergic perennial and infectious rhinitis. Zh Mikrobiol Epidemiol Immunobiol. 2003;3:66-71.

12. Greene $\mathrm{CE}$, Reinero $\mathrm{CN}$. Bacterial respiratory infections. In: Greene CE, editor. Infectious diseases of the dog and cat. $3^{\text {rd }}$ ed. St. Louis: Saunders; 2006. p. 866-82.

13. Hatkin J. Endemic malignant catarrhal fever at the San Diego wild animal park. J Wildl Dis. 1980;16(3):43943.

14. Campbell GA, Kosanke SD, Toth DM, White GL. Disseminated staphylococcal infection in a colony of captive ground squirrels (Citellus lateralis). J Wildl Dis. $1981 ; 17(2): 177-81$.
15. Miller MW, Hobbs NT, Williams ES. Spontaneous pasteurellosis in captive rocky mountain bighorn sheep (Ovis canadensis canadensis): clinical, laboratory, and epizootiological observations. J Wildl Dis. 1991;27(4):534-42.

16. Muro J, Ramis A, Pastor J, Velarde R, Tarres J, Lavin S. Chronic rhinitis associated with herpesviral infection in captive spur-thighed tortoises from Spain. J Wildl Dis. 1998;34(3):487-95.

17. McLaughlin GS, Jacobson ER, Brown DR, McKenna CE, Schumacher IM, Adams HP, et al. Pathology of upper respiratory tract disease of gopher tortoises in Florida. J Wildl Dis. 2000;36(2):272-83.

18. Salinas M, Francino O, Sánchez A, Altet L. Mycoplasma and herpesvirus PCR detection in tortoises with rhinitis-stomatitis complex in Spain. J Wildl Dis. 2011;47(1):195-200.

19. van den Bogaard AE, Stobberingh. Epidemiology of resistance to antibiotics. Links between animals and humans. Int J Antimicrob Agents. 2000;14(4):327-35. 